\title{
17 ANaLrzimG PUBLIC OPEN SOURCE POLICY: The Case Study of Venezuela
}

\author{
Edgar Maldonado \\ Andrea H. Tapia \\ College of Information Sciences and Technology \\ Pennsylvania State University \\ University Park, PA U.S.A.
}

\begin{abstract}
This research examines public open source software (OSS) adoption policies using a framework built upon the analysis of information and communication technology (ICT) policies. The legislative and objective framework is used to picture the formal public OSS policies applied in Venezuela. Preliminary results indicate negligence for the inclusion of the private sector in the migration plan. Future research looks for an analysis in situ of the activities carried out in the country, and the validation of the framework.
\end{abstract}

Keywords Open source software, open source development, national policy, Venezuela, Latin America

\section{INTRODUCTION}

The goal of this research is to demonstrate our thinking about the role of government in the service economy. Although this relationship is complex, we have chosen to highlight three aspects of this role: the government in the role of regulator, the government in the role of consumer, and the government in the role of thought leader.

It is often true that a national government will take an active role in the development and maintenance of an information-based service economy within its borders with the goal of furthering economic development. The shape this intervention takes differs from nation to nation. Governments, as primary decision makers, provide a set of measures

Please use the following format when citing this chapter:

Maldonado, E., and Tapia, A. H., 2008, in IFIP International Federation for Information Processing, Volume 267, Information Technology in the Service Economy: Challenges and Possibilities for the $21^{\text {st }}$ Century, eds. Barrett, M., Davidson, E., Middleton, C., and DeGross, J. (Boston: Springer), pp. 249-257. 
that, at least in their intent, will lead the country to continued economic and social development (Pieterse 2001, p. 3). Of particular interest is when a national government uses its powers to mandate the use of open source software and systems with the goal of influencing the course of development of the service economy within its borders.

The number of countries with policies that endorse or support the use of OSS in some way is significant and growing. The Center for Strategic and International Studies, in its report titled "Government Open Source Policies," identified 268 OSS public policies initiatives (CSIS 2007). However, very few governments have set their policy bar at the far end, making the move to OSS mandatory. Among all initiatives, six have been categorized as mandatory at a country level: Belgium, Denmark, Norway, Taiwan, Peru, and Venezuela. In addition to these six, the Minister of Economic Affairs of the Netherlands announced he Netherlands in Open Connection plan (Ministry of Economic Affairs 2007). Among other claims, the official document sets a deadline for the adoption of open source software in all ministries as April 2009. The Philippines is considering House Bill \#1716, which not only will make the use of OSS mandatory in public settings, but it will change the Philippines intellectual property legislation, making software a non-patentable invention (Casi 2007).

The reasons for this strong interventionist approach to OSS often fall into two main categories: overall social benefits and pragmatic arguments. The social benefits of using OSS are economic independence, the potential of OSS to contribute to solving the universal access problem, to increase local control and local economic growth, and to improve transparency and democratic accountability. The pragmatic arguments point out the interoperability, security, and cost of OSS (Ghosh 2005). In addition, OSS is seen as having potential for developing countries to create specific solutions for their particular needs, eliminating or reducing foreign dependencies (Weber 2003; Weerawarana and Weeratunga 2004).

This research examines the public OSS policies of Venezuela, which, because of high revenues from oil exports, finds itself in the unique position of having the economic ability to support an OSS migration plan for the entire nation. Venezuela (ranked $83^{\text {rd }}$ in the world in 2006-2007 by The Networked Readiness Index Ranking) is a developing country leapfrogging into the global information and service economy. The country has been rapidly crafting telecommunications policies and establishing ministries to enact and enforce them. Venezuela established its Ministry of Science and Technology in 1999 and its Ministry of Telecommunications and Informatics in 2007.

In the case of Venezuela, we see the national government influencing the growth of the technologically enabled service economy (1) in the role of regulator, as it make laws that mandate the use of OSS in public offices, (2) in the role of consumer, as an important sector of the working population are government employees and are becoming the consumers of this change, and (3) in the role of thought leader, as it attempts to persuade Venezuelan citizens to adopt OSS inside and outside the public sphere.

\section{ANALYTICAL FRAMEWORK DEVELOPMENT}

The circumstance of governments mandating OSS through legislation is relatively new and thus frameworks for analyzing these initiatives are few. One such framework is offered by the Centre for Strategic and International Studies, which characterized ublic 
OSS policies using two dimensions: jurisdiction and level of coercion. Jurisdiction includes state and local policies, and national level policies. The level of coercion is divided into four levels, in diminishing order: mandatory, preference, advisory, and research and development (CSIS 2007). Although this framework is useful, it does not help clarify the purpose of the policies or the role the government intends to take in terms of the development of the economy.

With this research, we seek to illustrate a new analytical framework that combines the two dimensions of the CSIS categorization into one and introduces policy goals and the government's role into the analysis. Both jurisdiction and level of coercion obtain their power via legitimate authority in the form of legislation. Therefore, in order to merge these two aspects into a single dimension, we find we need a means of categorizing legislation.

To accomplish this, we draw from Kelsen (2002), who introduced a model to explain the logical structure of law where general rules are found at the top and specific rules are found at the bottom. The rules at the bottom inherit their authoritative power from the top. The logical structure of law can be likened to a pyramid with the most fundamental and authoritative rules (the Grundnorm) at the top and the most particular rules (those applying to particular concrete situations) at the base. Kelsen's pyramid is represented with the constitution as a fundamental law at the top, general laws in the middle, and other forms of legal instruments at the bottom (for a detailed Kelsen's pyramid of Venezuela's law, see Naranjo 1982).

Building on Kelsen, we have created a truncated legislative pyramid with three levels: law level, decree level, and norm level. The law level includes any specific law (organic, special, ordinary, etc.). The decree level includes all decrees passed by executive positions (president and governors). Finally, the norm level consists of resolutions, orders, or other administration procedures usually passed by ministers or local authorities. Figure 1 illustrates a representation of the pyramid.

While adopting Kelsen categorization allows us to place policies in a continuum of most to least authoritative-coercive power, it does not address the nature of the policies themselves, especially in respect to information technologies.

In order to situate OSS polices according to their relationship with information technologies and development, we draw on the work of Alabau (1997). Nations seeking the development of a sector in their region typically follow guidelines given by the public sector. Alabau divides these government initiatives, aimed at growing the ICT sector, into four categories: (1) the stimulation of ICT initiatives in the private sector, (2) the stimulation of ICT initiatives in the public sector, (3) ICT deployment as part of territorial planning, and (4) regulation of ICT-related activities. Initiatives that fit the first category are those aimed at fueling the private sector by creating more jobs or improving competitiveness, and to all citizens in general by improving the quality of life. In the second category the policies seek to improve public activities by the introduction of ICTs. In the category of territorial planning are those initiatives in charge of the planning of a city or town; the planning is usually done with long-term thinking and the ICT deployment is an essential part of the overall infrastructure. Finally, the regulation category includes those initiatives that seek to achieve ideal circumstances for the development of ICTs (full competition, universal access, interoperability, etc.) (Alabau, 1997).

Policies that fit in the last category, regulation, usually have an associated intrinsic legal character and carry the authority of the government behind them. The legal char- 


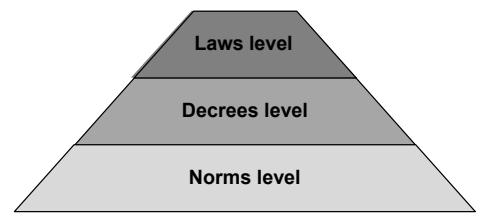

Public OSS Policies Legislative Pyramid

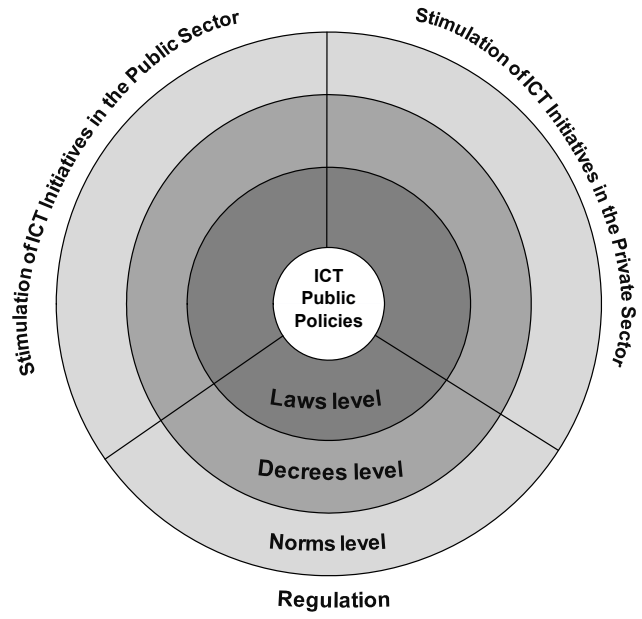

Legislative and Objective Public OSS Policies Framework

Figure 1. The Public OSS Policies Legislative Pyramid and the Legislative and Objective Framework

acter is the feature that assures national policy will achieve their initial goals. Although most regulations are created hoping that they will be accepted and followed, their legal status oftentimes determines their success. The stronger the legal nature of an ICT policy, the stronger the sanctions against noncompliance, the more likely the policy will have the desired effect.

Drawing from both the Kelsen and Alabau categorization schemes, we have the ability to analyze and categorize OSS policies on two axes: amount of authority/coercive power and form of policy tool toward economic development. The legislative and objective framework is represented in Figure 1.

The legislative and objective framework provides a practical tool to graphically interpret the reach and purpose of a specific ICT policy. We have taken the pyramid and expanded it to encompass a full circle. This circle represents three domains: public, private, and regulatory. This provides us with a mechanism to illustrate the form and domain for each OSS policy initiative.

\section{METHODOLOGY}

The principal tool used in this research is policy analysis. Policy analysis is defined by Nagel (1980) as "methods associated with determining the nature, causes, and effects of government decisions or policies designed to cope with specific social problems" (p. 3). Putt and Springer (1989) identified five major types of policy research, including exploration, description, causation, estimation, and choice. In the present work, we 
primarily engage in description and estimation activities. As a form of description policy research, we describe the policies of Venezuela (1) as they exist as physical documents and (2) as they are interpreted and carried out by authorities Policy research estimating activities, in this particular case, are limited given the lifespan of the phenomenon, but in that respect we look at the effects of the public OSS policies in Venezuela on enhancing the ICT sector of the country.

Our data comes from several official Venezuelan channels: the Ministry of Science and Technology website (http://www.mct.gov.ve), the National Center of Information Technology website (http://www.cnti.gob.ve), the National Assembly website (http:// www.asamblenacional.gov.ve), and FUNDACITE Merida website (http://www. fundacite-merida.gob.ve). Those websites make available all legal documents, including decrees, resolutions, law proposals, and minutes of legal meetings. There are four legal documents and two plans that constitute the core of the data used in this study (see Table 1). The legal documents are Resolution \#237, Resolution\#238, Decree 3,390, and the Telecommunications Law (renamed Infogobierno Law). The plans are the National Plan for Innovation, Ccience, and Technology 2005-2030 and the National Plan of Telecommunications, Informatics, and Postal Service.

This paper represents a small portion of a larger research project into public open source initiatives in Venezuela. These research methods complement other forms of qualitative data collection ongoing in Venezuela.

\section{PRELIMINARY FINDINGS}

The central policy motivating OSS change in Venezuela is Decree 3,390. This decree establishes the mandatory use of OSS in all National Public Administration (see Table 1). Using the legislative and objective framework, this policy falls in the middle ring on the public initiatives wedge. Venezuela also created open source academies (OSA) (Resolutions \#237; see Table 1) as an indirect method of stimulating the development and use of open source. The OSAs provide training to government employees and the general public on open source software from an end-user level to a developeradministrator level. In addition, there is an open source factory (OSF) initiative, created simultaneously with the OSAs. The OSFs are developing OSS to be used in government bodies (municipalities, hospitals, and elementary schools) and other forms of entrepreneurship sponsored by the government (small tourism-related businesses). Both initiatives can be categorized in the external ring of the framework on the public initiatives wedge.

The Infogobierno Law would provide a stronger authoritative-coercive support for the adoption of OSS since it would have more significant power than the Decree 3,390. This proposal has not yet passed. The delay may be due to the current crafting of the National Plan of Telecommunications, Informatics, and Postal Service 2007-2013. The preceding National Plan of Innovation, Science and Technology 2005-2030 was published in 2005 and included the adoption of OSS in public offices as one of its strategic goals. The 2007-2013 plan is expected to include this focus, but also take intou account the private sector and foreign investors. Venezuela current policies do not include a direct intervention in the private sector. Although it is possible that this sector is making a move to integrate itself to the migration processes. 
Table 1 Documents Used in this Work

\begin{tabular}{|c|c|c|c|}
\hline Date & $\begin{array}{c}\text { Governmental Body, } \\
\text { Type of document }\end{array}$ & Description & Objective \\
\hline 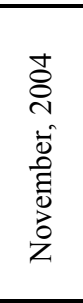 & $\begin{array}{l}\text { Minister of Science } \\
\text { and Technology, } \\
\text { Resolution } \# 237\end{array}$ & $\begin{array}{l}\text { For resolution of the } \\
\text { Minister of Science and } \\
\text { Technology, Marlene } \\
\text { Yadira Córdova; created } \\
\text { the Academia de software } \\
\text { Libre (Open Source } \\
\text { Academy). }\end{array}$ & $\begin{array}{l}\text { It is created the scientific-techno- } \\
\text { logical program of research, } \\
\text { denominated "Academia de } \\
\text { software Libre," this program will } \\
\text { have as an objective the promotion } \\
\text { of research, development, innova- } \\
\text { tion, and formation in the open } \\
\text { source software area. }\end{array}$ \\
\hline 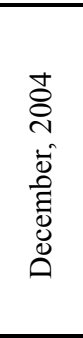 & $\begin{array}{l}\text { National Executive, } \\
\text { Decree 3,390 }\end{array}$ & $\begin{array}{l}\text { President of the Republic, } \\
\text { Hugo Chávez Frías } \\
\text { signed Decree } 3,390 \text {. } \\
\text { The decree establishes } \\
\text { open source as a } \\
\text { mandatory first option in } \\
\text { all government systems. }\end{array}$ & $\begin{array}{l}\text { The National Public Administra- } \\
\text { tion will use open source software } \\
\text { as first priority in its systems, pro- } \\
\text { jects, and informatics services. To } \\
\text { such aims, all of the institutions } \\
\text { and offices of the National Public } \\
\text { Administration will initiate the } \\
\text { progressive adoption of open } \\
\text { source software. }\end{array}$ \\
\hline 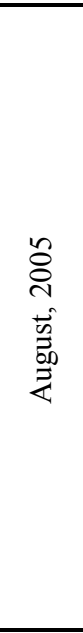 & $\begin{array}{l}\text { National Assembly, } \\
\text { Technologies of } \\
\text { Information Law; first } \\
\text { discussion }\end{array}$ & $\begin{array}{l}\text { Article } 75 \text { of this law } \\
\text { clearly describes the } \\
\text { characteristics of the } \\
\text { software that the } \\
\text { government should use. }\end{array}$ & $\begin{array}{l}\text { The organs and agencies of the } \\
\text { Public Power will have to use, } \\
\text { primarily and by preference in } \\
\text { their systems of information tech- } \\
\text { nologies, the computer science } \\
\text { programs and applications whose } \\
\text { licenses or contracts guarantee in } \\
\text { an irrevocable way access to the } \\
\text { source code of the program by the } \\
\text { user; to execute it with any inten- } \\
\text { tion; to modify it and to redistri- } \\
\text { bute the original program as much } \\
\text { as its modifications in the same } \\
\text { decided conditions of licensing to } \\
\text { the original program, without } \\
\text { having to pay exemptions to the } \\
\text { previous developers. }\end{array}$ \\
\hline 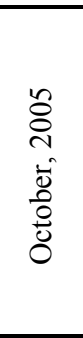 & $\begin{array}{l}\text { Minister of Science } \\
\text { and Technology, } \\
\text { National Plan of } \\
\text { Innovation, Science } \\
\text { and Technology } \\
2005-2030 \\
\text { (NPSTI) }\end{array}$ & $\begin{array}{l}\text { The Minister of Science } \\
\text { and Technology pub- } \\
\text { lished a 152-page docu- } \\
\text { ment with the National } \\
\text { Plan of Science Technol- } \\
\text { ogy and Innovation. } \\
\text { Open source is used as } \\
\text { part of the strategic goals } \\
\text { of the plan. }\end{array}$ & $\begin{array}{l}\text { Strategic goal \#5: Migration of } \\
\text { the systems of the public admin- } \\
\text { istration to open source systems } \\
\text { until reaching a complete adoption } \\
\text { within the technological platforms } \\
\text { of the state, in a period no longer } \\
\text { than } 5 \text { years. }\end{array}$ \\
\hline
\end{tabular}




\begin{tabular}{|c|c|c|c|}
\hline Date & \begin{tabular}{|c|} 
Governmental Body, \\
Type of document
\end{tabular} & Description & Objective \\
\hline 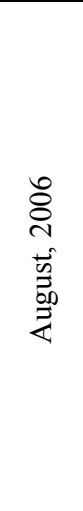 & $\begin{array}{l}\text { National Assembly, } \\
\text { Infogobierno Law }\end{array}$ & $\begin{array}{l}\text { The National Assembly } \\
\text { began the second discus- } \\
\text { sion of the Law of Tech- } \\
\text { nologies of Information. } \\
\text { The law now is renamed } \\
\text { Infogobierno Law. The } \\
\text { new version has kept a } \\
\text { good part of the content } \\
\text { of the prior version. } \\
\text { Article } 67 \text { specifies the } \\
\text { use of open source } \\
\text { software in government } \\
\text { offices. }\end{array}$ & $\begin{array}{l}\text { The Public Power will have to } \\
\text { guarantee that in their systems of } \\
\text { information technologies, the } \\
\text { computer science programs and } \\
\text { applications fulfill the following } \\
\text { characteristics: (1) Access to all } \\
\text { source code and the transference } \\
\text { of the knowledge associated for its } \\
\text { understanding. (2) Freedom of } \\
\text { modification. (3) Freedom of use } \\
\text { in any area, application, or inten- } \\
\text { tion. (4) Freedom of publication } \\
\text { of the source code and its modifi- } \\
\text { cations }\end{array}$ \\
\hline 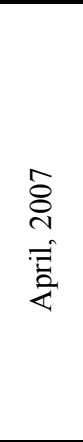 & $\begin{array}{l}\text { Minister of } \\
\text { Telecommunications } \\
\text { and Informatics, } \\
\text { National Plan of } \\
\text { Telecommunications, } \\
\text { Informatics, and } \\
\text { Postal Service 2007- } \\
\text { 2013; in process }\end{array}$ & $\begin{array}{l}\text { The Venezuelan govern- } \\
\text { ment announces the } \\
\text { National Plan of } \\
\text { Telecommunications, } \\
\text { Informatics, and Postal } \\
\text { Service 2007-2013. }\end{array}$ & $\begin{array}{l}\text { Using online surveys and board } \\
\text { discussions with stakeholders from } \\
\text { different sectors of the society and } \\
\text { economy of the country, the } \\
\text { Minister of the Public Power of } \\
\text { Telecommunications and Informa- } \\
\text { tics is creating a roadmap for the } \\
\text { next } 5 \text { years in the area. The delay } \\
\text { in approving the Infogobierno Law } \\
\text { could be due to the need to fit the } \\
\text { legal document to the new national } \\
\text { plan. }\end{array}$ \\
\hline
\end{tabular}

Venezuela's open source software policies are still being crafted. The National Plan of Telecommunications, Informatics, and Postal Service 2007-2013 will be published soon. Along with this plan, a final version of the Infogobierno Law will be passed. Given the direction of the legal framework of Venezuelan OSS policies, is likely that the mandatory character of OSS will be kept in the new law. The existing initiatives are portrayed in the legislative and objective framework in Figure 2.

\section{RESULTS FORTHCOMING}

The goal of this research is to demonstrate our thinking about the role of government in the service economy. We have focused on government interventions through laws that mandate the use of open source software and systems. We have created a framework that looks at these interventions through three lenses providing one picture. The first lens is the amount of coercive authority granted the initiative, the second is the public arena in which the initiative seeks to have an effect, and the third is the role the government has taken in each. We have chosen to highlight three aspects of this role: the government in the role of regulator, the government in the role of consumer, and the government in the role of thought leader. 


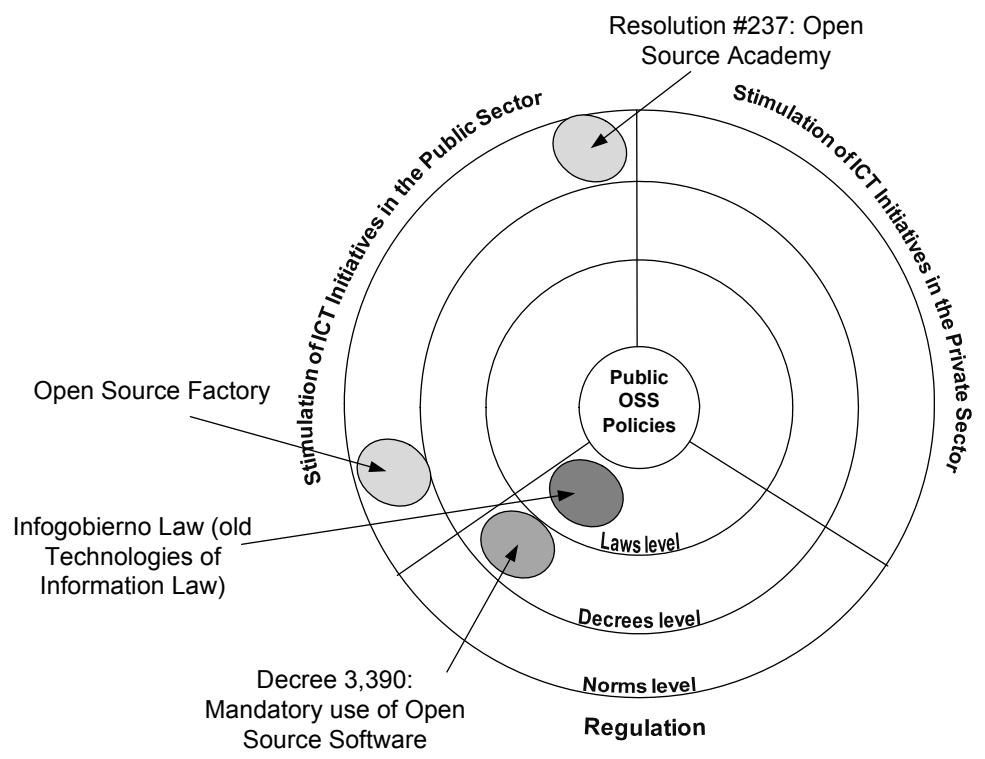

Figure 2. Venezuela's Public OSS Initiatives

As mentioned earlier, this policy analysis work is part of a larger research program investigating public open source. We are currently gathering data in Venezuela. We believe that the analytical framework we have created will not only help us to analyze the policy efforts in Venezuela, but will provide a mechanism to compare efforts across countries that have similar OSS initiatives. Once our data is fully collected and analyzed, we expect to complete the entire picture of the Venezuelan migration using the framework presented in this work. Once the framework is refined and validated, we anticipate it will be possible to apply it to other types of policies influencing the development of the technology-enabled service economy within a nation.

\section{References}

Alabau, A. 1997. "Telecommunications and the Information Society in European Regions," Telecommunications Policy (21:8), pp. 761-771.

Casiño, T. A. 2007. "Republic of the Philippines House Bill No. 1716," August 1 (http://www. bayanmuna.net/data_files/HB/HB-1716-FOSS.pdf).

CSIS. 2007. "Government Open Source Polices," Center for Strategic and International Studies, Washington, DC, August (http://www.csis.org/tech/it/\#oss)

Ghosh, R. A. 2005. "The European Politics of F/OSS Adoption," in The Politics of Open Source Adoption, J. Karaganis and R. Latham (eds.), New York: Social Science Research Council.

Kelsen, H. 2002. Pure Theory of Law (translation from the second German edition by M. Knight), Berkeley: University of California Press, 1967; reprinted by The Lawbook Exchange, Ltd..

Nagel, S. 1980. The Policy-Studies Handbook, Lexington, MA: Lexington Books. 
Naranjo, Y. 1982. Introduccion al derecho, Caracas: Ediciones Libreria Destino.

Pieterse, J. N. 2001. Development Theory: Deconstrution/Reconstruction, London: Sage Publications.

Putt, A. D., and Springer, J. F. 1989. Policy Research: Concepts, Methods, and Applications, Englewood Cliffs, NJ: Prentice Hall.

Weber, S. 2003. "Open Source Software in Developing Economies ," unpublished manuscript, University of California, Berkeley (http://www.ssrc.org/programs/itic/publications/ ITST_materials/webernote2.pdf).

Weerawarana, S., and Weeratunga, J. 2004. Open Sources in Developing Countries, Stockholm: Swedish International Development Cooperation Agency, January (http://www.eldis.org/ fulltext/opensource.pdf)..

\section{About the Authors}

Edgar Maldonado is a Ph.D. candidate in the College of Information Sciences and Technology at Pennsylvania State University. Edgar will complete his degree in 2008. His research focuses on national-level telecommunication policies specifically directed at open source software. In addition, his work centers on policy in developing countries and their influence on the development of knowledge-based societies and economies. He has an undergraduate degree in Electronic Engineering from Simón Bolívar University, Caracas, Venezuela. Before entering graduate school, Edgar worked as a software support engineer for banking networks, with projects in Venezuela, Trinidad and Tobago, Panamá, Guatemala, and the Cayman Islands. Edgar can be reached at eam264@psu.edu.

Andrea H. Tapia is an assistant professor at the College of Information Sciences and Technology at Pennsylvania State University. Andrea is a sociologist with expertise in social research methods and social theory, applying those to the study of information and communication technologies and their context of development, implementation, and use. Her guiding research question is, "What is the role that technology plays in institutional patterns of power, hierarchy, governance, domination and resistance?" The domains of interest in which she asks this question are government and public institutions, virtual worlds, and social policy. Andrea's work has been funded by the U.S. National Science Foundation, the U.S. Department of Defense, the United Nations, and Penn State's Schreyer's Honors College. Her work has appeared in The Information Society, Government Information Quarterly, Database for Information Systems Research, Communications of the ACM, Science Technology and Human Values, and Information Technology and People. Andrea can be reached at atapia@ist.psu.edu. 